Sri Lanka J. Aquat. Sci. 11 (2006): 1-19

\title{
Population dynamics of Gerres abbreviatus Bleeker, 1850 from the Parangipettai waters, Southeast coast of India
}

\author{
S. KUGANA THAN* \\ Department of Zoology, University of Jaffna, Jaffna, Sri Lanka \\ *E-mail: shanthi86@rediffmail.com
}

\begin{abstract}
The population dynamics of Gerres abbreviatus from the Parangipettai waters, Southeast coast of India was investigated based on length frequency data, using FiSAT software. Growth parameters of $G$. abbreviatus were estimated using ELEFAN I method. The theoretical ages at length zero $\left(\mathrm{t}_{0}\right)$ were estimated by substituting the asymptotic length $\left(\mathrm{L}_{\infty}\right)$ and growth coefficient $(\mathrm{K})$ in Pauly's equation. The fitted von Bertalnaffy's growth equations for male and female $G$. abbreviatus were $\mathrm{L}_{\mathrm{t}}=27.8[1-\exp$ $\{-1.30(\mathrm{t}+0.1236)\}]$ and $\mathrm{L}_{\mathrm{t}}=28.2[1-\exp \{-1.36(\mathrm{t}+0.1175)\}]$ where $\mathrm{L}_{\infty}$ values are in $\mathrm{cm}, \mathrm{K}$ values are on annual basis and $\mathrm{t}_{0}$ values are in years. The estimated growth performance index $(\varnothing)$ for male and femaleG. abbreviatus were 3.002 and 3.034 respectively while the estimated life spans of male and female $G$. abbreviatus were 2.18 and 2.08 years. Instantaneous rates of total mortality $(Z)$ estimated by length converted catch curve for male and female G. abbreviatus were 3.06 and $2.99 \mathrm{yr}^{-1}$ respectively. Natural mortality (M) estimated by Pauly's empirical equation for male and femal@G. abbreviatus were 2.24 and $2.29 \mathrm{yr}^{-1}$ and the estimated fishing mortality for male and female G. abbreviatus were 0.82 and $0.70 \mathrm{yr}^{-1}$ respectively. Relative yield per recruit analysis incorporating probabilities of capture indicates that $G$. abbreviatus in the Parangipettai waters is exploited below the optimum level indicating scope for increase in fishing efforts without leading to overexploitation.
\end{abstract}

\section{Introduction}

Gerres abbreviatus (Osteichthyes: Gerreidae) is an economically important food fish species. Iwatsuki et al. (1998) reported deep-bodied gerreid fish, $G$. erythrourus as a valid gerreid and a senior synonym of $G$. abbreviatus. This species is distributed widely in the Indo-Pacific region and support fisheries significantly in many countries such as Bahrain, Fiji islands, 
India, Kiribati, Malaysia, Mexico, Philippines, Qatar, Saudi Arabia, Sri Lanka, United Arab Emirates and United States of America (Froese \& Pauly 2000). FAO annual catch data showed that 4370 metric tones of silver biddies were captured in Philippines during 1998 while 1730 metric tones in Kiribati and 1324 metric tones in United Arab Emirates (Froese \& Pauly 2000). The maximum catch of 9658 metric tons was recorded in Mexico during 1990 (Froese \& Pauly 2000).

Silver biddies constitute an important fishery in the Pulicat Lake (Prabhakara Rao 1968), Chilka Lake, India (Patnaik 1971) and in Africa in the Kosi system (Blaber 1978; Cyrus 1980). In Pulicat Lake, where the silver biddies are esteemed as delicious food and a major portion of the landings consumed locally in the fresh as well as dried condition, $G$. oyena along with G. filamentosus and G. limbatus constitute an important fishery. Biology of these species was studied by Prabhakara Rao (1970). The other species of Gerres recorded from the Lake are G. oyena, G. punctatus and G. limbatus, which are of little importance. Day (1878) reported silver biddies to be common in river Hooghly. From Chilka Lake it was first recorded by Chaudhuri (1923) and subsequently some information on its landings, fishery, biology and distribution were described by Devasundaram (1954), Jones \& Sujasingani (1954) and Roy \& Sahoo (1962) and Jhingran \& Natarajan (1966 \& 1969).

Perusal of literature showed that length-weight relationship, condition factor and age and growth of silver biddies have been studied by several workers. Important contributions on this subject in world waters are ofGerres oyena from Arabian gulf waters (El-Agamy 1988); $G$. oyena from Tarawa lagoon, Kiribati (Yeeting 1990); Gerres filamentosus, G. ovulatus and G. oyena from Réunion island, Indian ocean (Letourneur 1998); Diapterus rhombeus, Eucinostomus argenteus and E. gula from São Sebastião System, Southeastern Brazil (Muto et al. 2000) and G. oblongus from Jaffna lagoon, Sri Lanka (Sivashanthini \& Abeyrami 2003). Records from Indian waters are of G. oyena from the Pulicat Lake (Prabhakara Rao 1970); G. setifer from Chilka Lake, India (Patnaik 1971); G. lucidus from the Pulicat Lake (Kaliyamurthy et al. 1986); Daysciaena albida and G. filamentosus from Cochin waters (Kurup \& Samuel 1987 \& 1991) and G. setifer from Mangalore waters (Anantha \& Santha Joseph 1995) and G. setifer from Parangipettai waters, south India (Sivashanthini \& Ajmal Khan 2004).

In Parangipettai waters boat seines, gill-nets, and long lines are mainly employed for fishing silver biddies. However among the employed methods $80 \%$ of the capture fishery is by boat seines. A boat seine is a very long net, with or without a bag in the centre, which set from a boat for surrounding a certain area and is operated with two (long) ropes fixed to its ends (for hauling and herding the fish). As majority of the captured fishery is by boat seines, the length frequency data obtained from boat seines were incorporated in the present study in order to suggest themanagement of silver biddy fishery. Other types of gear are used only sporadically and therefore 
samples could not be obtained regularly. Catamarans are the most common traditional craft operated along the Parangipettai coastal waters. But this has become a rare fishing method in the Parangipettai waters, nowadays.

The biology of the species belonging to the family Gerreidae has been little investigated and most published information consists of incidental records or notes in general surveys (Froese and Pauly 2000). As no detailed study on biology and population dynamics of this species is reported, the present study was undertaken to get information on the maximum size and age of fish, growth parameters, mortality and exploitation rate of Gerres abbreviatus of the Parangipettai waters based on length frequency data .

\section{Materials and Methods}

\section{Collection of data}

Samples for the present study were collected from the commercial boat seine catches of Parangipettai waters ( $\left(11^{0} 29^{\prime} \mathrm{N}\right.$ and $\left.79^{\circ} 46^{\prime} \mathrm{E}\right)$ at weekly intervals during September 2001 to August 2003. The male and female fishes were identified by examining the gonads and the total length (TL) was measured to the nearest $1 \mathrm{~mm}$ from the tip of snout to the tip of caudal fin using a measuring board. A total of 4198 specimens (2108 males and 2090 females) of $G$. abbreviatus ranging in total length from 7.5 to $27.9 \mathrm{~cm}$ were analyzed for the age and growth studies. The length frequency data were grouped sex wise into $1 \mathrm{~cm}$ class intervals, sequentially arranged for two years and used for estimation of growth. In the present study length frequency analysis were done with FiSA T II (Gayanilo \& Pauly 1997).

\section{Analysis of data}

The length frequency data of $G$. abbreviatus in the boat seine catches were analyzed using ELEFAN I routine of FiSA T II software (Gayanilo \& Pauly 1997). The following stepwise procedure was adopted to estimate and $\mathrm{K}$ and for correction of length frequency data for mesh selection (Sparre \& Venema 1992; Amarasinghe \& De Silva 1992; Amarasinghe, 2002).

- Estimation of an initial value for asymptotic length $\left(\mathrm{L}_{\infty}\right)$ and $\mathrm{Z} / \mathrm{K}$ ( $\mathrm{Z}=$ total mortality and $\mathrm{K}=$ growth coefficient) using the Powell-W etherall method (Powell 1979; Wetherall 1986).

- Preliminary estimation of asymptotic length $\left(\mathrm{L}_{\infty}\right)$ and growth coefficient (K) using the initial estimates of $\mathrm{L}_{\infty}$ estimated by PowellW etherall method.

- Estimation of probabilities of capture by detailed analysis of left ascending part of the catch curve using the preliminary estimation made on the asymptotic length $\left(\mathrm{L}_{\infty_{0}}\right)$, growth coefficient $(\mathrm{K})$ and computed $\mathrm{d}$. 
- Correction of the original length frequencies using probabilities of capture (Pauly 1986a, b \& c) for incomplete selection for length classes smaller than the first fully selected length through appropriate routine.

- Estimation of best optimized estimates of $\mathrm{I}_{\infty}$ and $\mathrm{K}$ through ELEFAN I routine (Gayanilo \& Pauly 1997) from the corrected length frequency data.

ELEFAN I routine of FiSA T II software (Gayanilo \& Pauly 1997) attempts to combine the logic of the Peterson method and that of modal progression analysis with a minimum of subjective inputs (Pauly 1983). Lo and $\mathrm{K}$ values were obtained through the four options such as, curve fitting by eye, response surface analysis, scan of $\mathrm{K}$ - values and automatic search routine. In this method the growth parameters $\mathrm{I}_{\infty}$ and $\mathrm{K}$ were estimated following the von Bertalanffy growth equation (von Bertalanffy 1938). The equation for growth in length is given by,

$$
\mathrm{L}_{\mathrm{t}}=\mathrm{L}_{\infty}\left[1-\exp \left\{-\mathrm{K}\left(\mathrm{t}-\mathrm{t}_{0}\right)\right\}\right]
$$

where $L_{t}$ is the length at age $t, L_{\infty}$ the asymptotic length $K$ the growth coefficient and ' $b$ ' theoretical age at which fish would have had zero length if they had always grown according to the above equation. The most optimized $\mathrm{L}_{\infty}$ and $\mathrm{K}$ values were obtained by ELEFAN I - automatic search routine and the restructured length frequency histograms were also obtained. The growth performance index $(\varnothing)$ for $G$. abbreviatus male and female was computed using the following equation(Pauly \& Munro 1984):

$$
\varnothing=\log _{10} \mathrm{~K}+2 \log _{10} \mathrm{~L}
$$

As ELEFAN cannot estimate the 6 value from the length-frequency data, a very approximate value of ' $t_{0}$ ' was estimated by substituting the $L_{\infty}$ (in $\mathrm{cm})$ and $\mathrm{K}\left(\right.$ year $\left.^{-1}\right)$ in the following equation (Pauly 1983).

$$
\log \left(-\mathrm{t}_{0}\right) \approx-0.3922-0.2752 \log \mathrm{L}_{\infty}-1.038 \log \mathrm{K} .
$$

Longevity was obtained from the following equation (Pauly, 1983):

$$
\mathrm{t}_{\max }=\mathrm{t}_{0}+3 / \mathrm{K}
$$

where $t_{\max }$ is the approximate maximum age the fish of a given population would reach.

The total mortality coefficient $(Z)$ was estimated using length converted catch curve analysis (Gayanilo \& Pauly 1997) in the FiSA T II program using the input parameters $\mathrm{L}_{\infty}, \mathrm{K}$ and $\mathrm{t}_{0}$. The theoretical equation used in this analysis is,

$\operatorname{Ln}\left(\mathrm{N}_{\mathrm{i}} / \mathrm{dt}_{\mathrm{i}}\right)=\mathrm{a}+$ b.t $_{\mathrm{i}}$

where $\mathrm{N}_{\mathrm{i}}$ is the number of fish in length class $\mathrm{i}$, dt is the time needed for the fish to grow through length class $i, t$ is the age corresponding to the mid length of class $i$, and where $b$, with sign changed, is an estimate of $Z$. The histogram showing probability of capture for each size class was obtained by 
backward extrapolation of the straight portion of the right descending part of the catch curve. The length at first capture $\mathrm{L}_{c}$ (length at $50 \%$ capture) was obtained from the plot of cumulative probability of capture against mid-length of class interval, through detailed analysis of ascending part of catch curve.

Estimation of natural mortality rate was obtained through Pauly's empirical model(Pauly 1980),

$\ln \mathrm{M}=-0.0152-0.279 \ln \mathrm{L}_{\infty}+0.06543 \ln \mathrm{K}+0.4634 \ln \check{\mathrm{T}}$

where $\mathrm{M}$ is the natural mortality, $\mathrm{L}_{\infty}$ is in $\mathrm{cm}, \mathrm{K}$ is annual and $\breve{\mathrm{T}}$ is the mean annual temperature $\left(\right.$ in $^{\circ} \mathrm{C}$ ), which is taken as $30^{\circ} \mathrm{C}$.

Fishing mortality (F) was calculated using the formula,

$Z=M+F$

Exploitation rate (E) was determined from the relationship,

$$
\mathrm{E}=\mathrm{F} / \mathrm{Z} \text {. }
$$

The relative yield per recruit $(\mathrm{Y} / \mathrm{R})$ was predicted by considering $\mathrm{Y}^{\prime} / \mathrm{R}$ as a function of $\mathrm{U}$ and $\mathrm{E}$ and $\mathrm{M} / \mathrm{K}$ as a constant ' 1 ' by employing Beverton and Holt $Y / R$ analysis (selection ogive) in the FiSA T package. The relative yield per recruit equation which gives a quantity proportional to YR was derived from the method of Beverton \& Holt (1966) through a number of algebraic manipulations. The predicted values were obtained by substituting the input parameters of $\mathrm{L}_{\mathrm{c}} / \mathrm{L}_{\infty}\left(\mathrm{L}_{\mathrm{c}}\right.$ is the minimum length captured; obtained from the extrapolation of length converted catch curve) and $M / K$ in the FiSA T II package (Gayanilo \& Pauly 1997) and according to the model,

$Y^{\prime} / R=E U^{M / K}\left[1-(3 U / 1+m)+\left(3 U^{2} / 1+2 m\right)-U^{3} /(1+3 m)\right]$

where,

$m=(1-E) /(M / K)=K / Z$

$U=1-\left(L d L_{\infty}\right)$

( $U$ is the fraction of growth to be completed by the fish after entry into the exploitation phase)

$E=F / Z$ (exploitation rate)

The assumptions considered in this model being fishing and natural mortalities are constant from the moment of entry to the exploited phase, recruitment is constant and the length-weight relationship has the exponent 3.

\section{Results}

The Powell-Wetherall plots for male and femaleGerres abbreviatus are shown in Figs. 1a and $1 \mathrm{~b}$ respectively. The analysis of length frequency 
data by the Powell-Wetherall method gave an initial estimate of $\mathrm{L}$ value of $29.4 \mathrm{~cm}$ and $\mathrm{Z} / \mathrm{K}$ value of 2.374 for males and $\mathrm{L}_{\infty}$ value of $28.8 \mathrm{~mm}$ and $\mathrm{Z} / \mathrm{K}$ value of 2.014 for females. Initial estimate of $\mathrm{K}$ values for male and female obtained from K-scan in the ELEFAN I were 1.35 and 1.4 respectively. The optimized values for $\mathrm{K}$ and $\mathrm{L}_{\infty}$ obtained by the ELEFAN I were 1.3 year $^{1}$ and $27.8 \mathrm{~cm}$ for males and $1.36 \mathrm{yr}^{-1}$ and $28.2 \mathrm{~cm}$ for females respectively. The non seasonalized restructured length frequency histograms with growth curves for males and females are shown in Figs. 2a and 2b. The estimated growth performance index (Ø) for $G$. abbreviatus male and female were 3.002 and 3.034. The estimated $t_{0}$ values for males and females were -0.1236 and 0.1175 respectively.

The von Bertalnaffy's growth equations for G. abbreviatus can be expressed as:

Male: $\mathrm{L}_{\mathrm{t}}=27.8[1-\exp \{-1.30(\mathrm{t}+0.1236)\}]$

Female: $\mathrm{L}_{\mathrm{t}}=28.2[1-\exp \{-1.36(\mathrm{t}+0.1175)\}]$

Estimated longevity for male and femaleG. abbreviatus calculated from Pauly's equation is 2.18 and 2.08 years respectively.

(a)

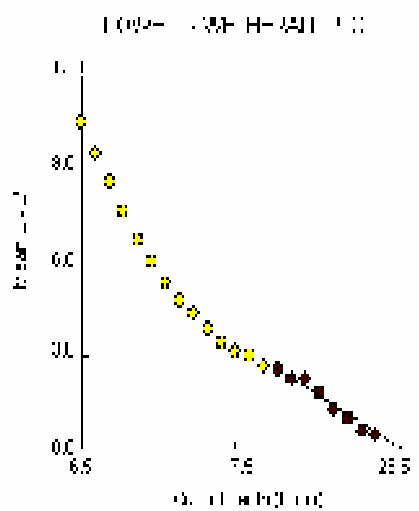

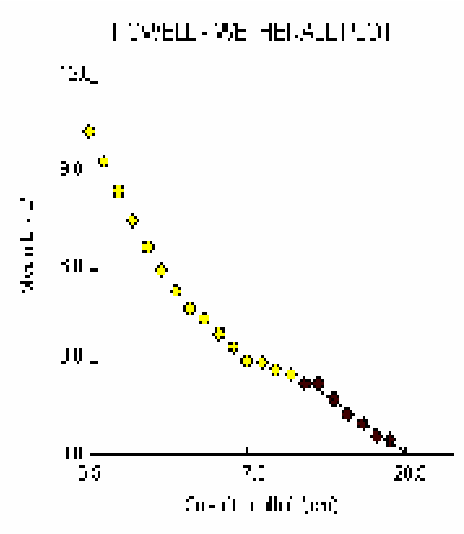

(b)

Fig. 1. Powell-W etherall plots of maleGerres abbreviatus (1a) and female $G$. abbreviatus (1b). 


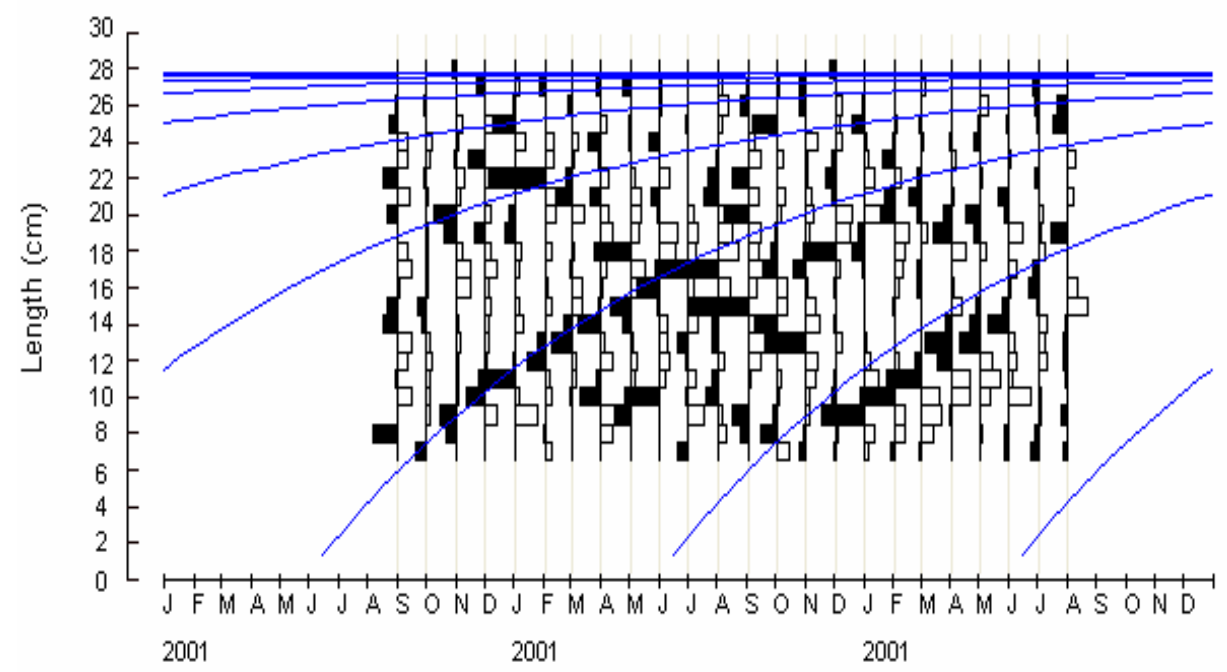

Fig. 2a. Growth curves of male Gerres abbreviatus drawn using ELEFAN I programme $\left(\mathrm{L}_{\infty}=27.8 \mathrm{~cm}\right.$ and $\left.\mathrm{K}=1.3 \mathrm{yr}^{-1}\right)$

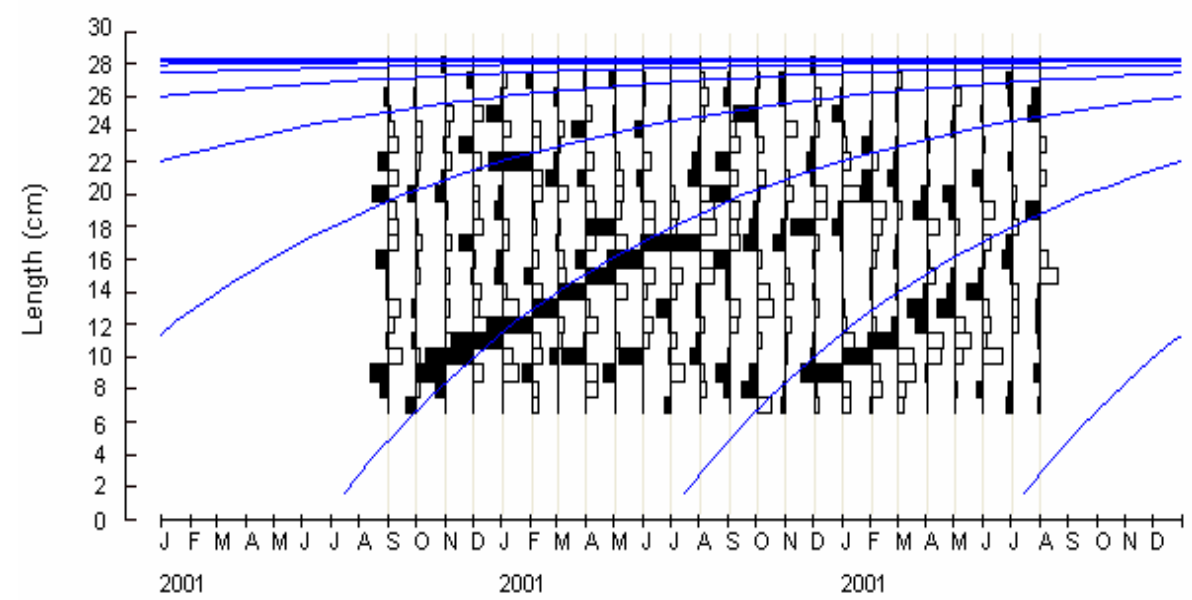

Fig. 2b. Growth curve of female Gerres abbreviatus drawn using ELEFAN programme $\left(\mathrm{L}_{\infty}=28.2 \mathrm{~cm}\right.$ and $\left.\mathrm{K}=1.36 \mathrm{yr}^{-1}\right)$

The length-converted catch curves for males and females are shown in Figs. 3a and 3b. The length-converted catch curve gave a $Z$ value of 3.06 $\mathrm{yr}^{-1}$ (confidence interval of $\mathrm{Z}=2.44-3.68$; standard deviation of the slope $=$ $0.236 ; \mathrm{r}=-0.9744)$ for males and $2.99 \mathrm{yr}^{-1}$ [95\% of confidence interval $(\mathrm{CI})$ of $Z=2.29-3.7$; standard deviation of the slope $=0.289 ; \mathrm{r}=-0.9732]$ for females. The histogram showing probability of capture for each size class obtained by backward extrapolation of the straight portion of the right 
descending part of the catch curve for male and female are shown in Figs. 4a and $4 \mathrm{~b}$. The lengths at first capture $\mathrm{L}_{\mathrm{c}}$ (length at $50 \%$ capture) estimated by backward extrapolation of the straight portion of the right descending part of the catch curve were $7.29 \mathrm{~cm}$ and $7.25 \mathrm{~cm}$ for male and female Gerres abbreviatus respectively.

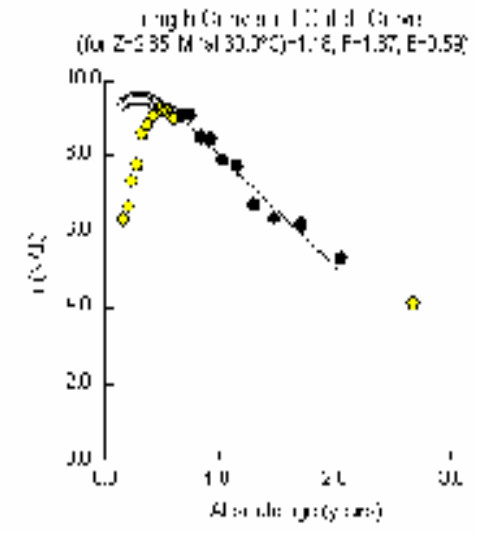

(a) male

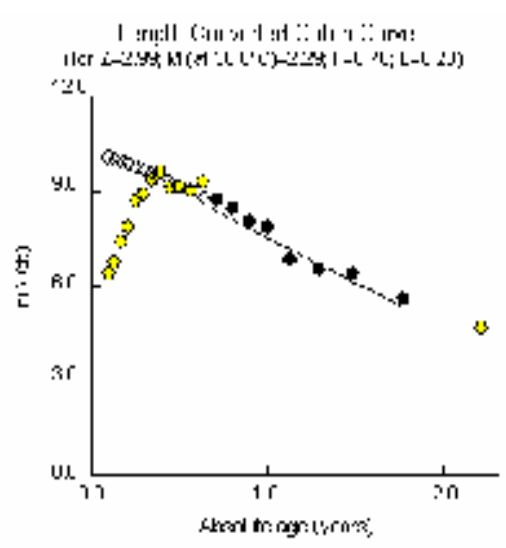

(b) female

Fig. 3. Length-converted catch curve of male and femaleGerres abbreviatus (a) males $\left[\mathrm{L}_{\infty}=27.8 \mathrm{~cm}, \mathrm{~K}=1.3 \mathrm{yr}^{-1}\right]$,(b) female $\left[\mathrm{L}_{\infty}=28.2 \mathrm{~cm}, \mathrm{~K}=1.36 \mathrm{yr}^{-1}\right]$

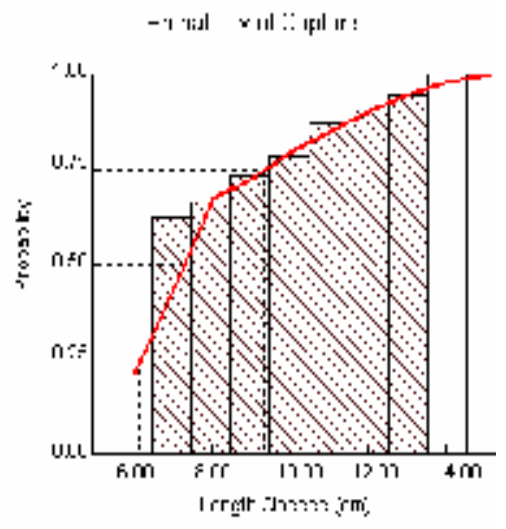

(a) male

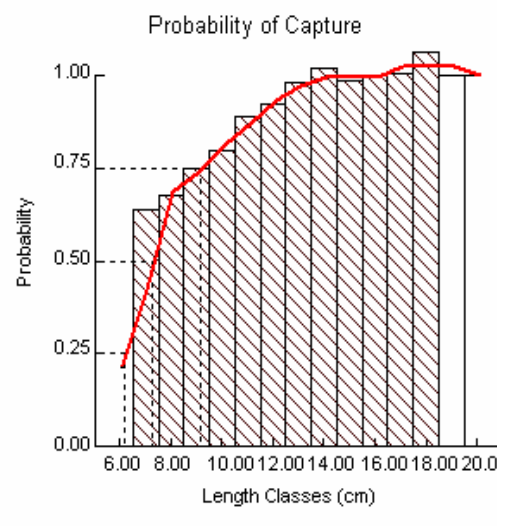

(b) female

Fig. 4. Probability plots of male Gerres abbreviatus $\left(\mathrm{L}_{\infty}=27.8 \mathrm{~cm}, \mathrm{~K}=1.3\right.$ $\left.\mathrm{yr}^{-1}\right)$ and female $G$. abbreviatus $\left(\mathrm{L}_{\infty}=28.2 \mathrm{~cm}, \mathrm{~K}=1.36 \mathrm{yr}^{-1}\right)$ 
The natural mortality coefficient (M) obtained through Pauly's empirical model at $30^{\circ} \mathrm{C}$ surface temperature was 2.24 year $^{-1}$ for males and $2.29 \mathrm{yr}^{-1}$ for females. Therefore, the computed instantaneous fishing mortality coefficient $(\mathrm{F})$ for males and females are 0.82 and $0.70 \mathrm{yir}^{-1}$ respectively. The respective current exploitation ratio (E) for males and females are 0.27 and 0.23 . The fraction of growth to be completed by the fish after entry into the exploitation phase (U) for males and females are 0.55 in both instance. Two dimensional relative yield per recruit prediction models incorporating probabilities of capture for males and females are given in Figs. 5a and 5b and the isopleth diagrams are given in Figs. $6 \mathrm{a}$ and $6 \mathrm{~b}$. The selective ogive procedure for the analysis of relative yield-per-recruit gave predicted value of $0.55\left(\mathrm{E}_{\max }\right)$ for male and female $G$. abbreviatus. The computed current exploitation rates $(E)$ of 0.27 for males and 0.23 for females are well below the predicted $\mathrm{E}_{\max }$ of 0.55 for males and females. Relative yield per recruit analysis incorporating probabilities of capture indicates that more yields could be obtained by a reasonable increase in the effort without necessarily leading to over exploitation. Also decrease in size at first capture of $G$. abbreviatus to optimize yield would allow the stock optimally exploited, theoritically. According to the isopleth diagrams (for male and female) the optimum values of $\mathrm{L}_{\mathrm{c}} / \mathrm{L}_{\infty}$ (Figs. 6a and 6b) to obtain optimum exploitation rate was between 0.2 and 0.35 . Therefore the optimum $\mathrm{L}_{c}$ could be between $5.56 \mathrm{~cm}$ and 9.73 $\mathrm{cm}$ for an optimally exploited $(\mathrm{E}=0.55) G$. abbreviatus fishery.

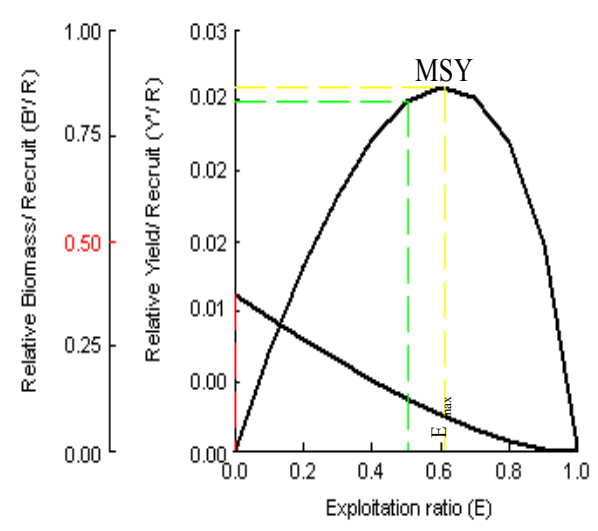

a) Male

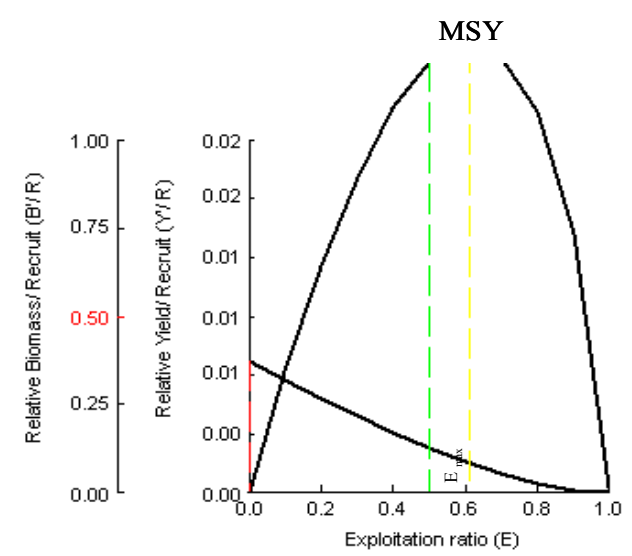

b) Female

Fig. 5a. Relative $\mathrm{Y}^{\prime} / \mathrm{R}$ and $\mathrm{B}^{\prime} / \mathrm{R}$ using selective ogive of male Gerres abbrovistus

Fig. $a b b i$

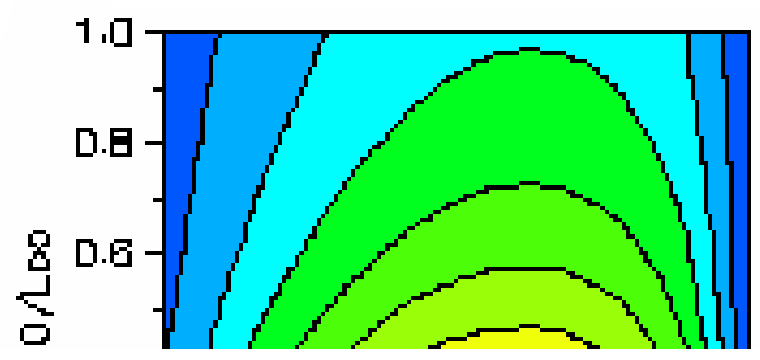
EemaleGerres 
Fig. 6a. Yield isopleth diagram for maleGerres abbreviatus

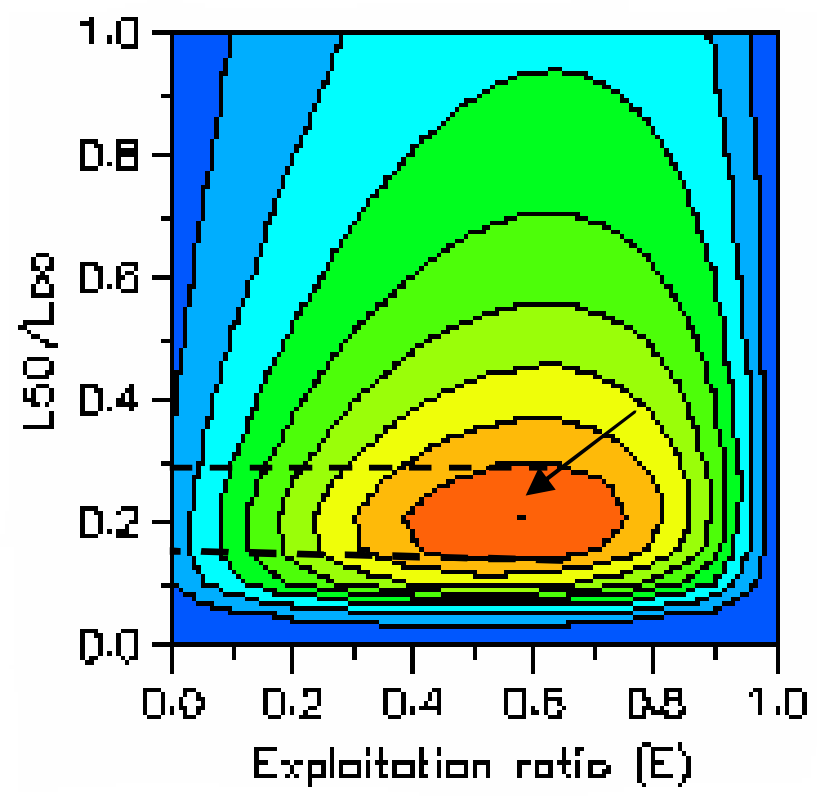

b) Female

Fig. 6b. Yield isopleth diagram for femaleGerres abbreviatus 


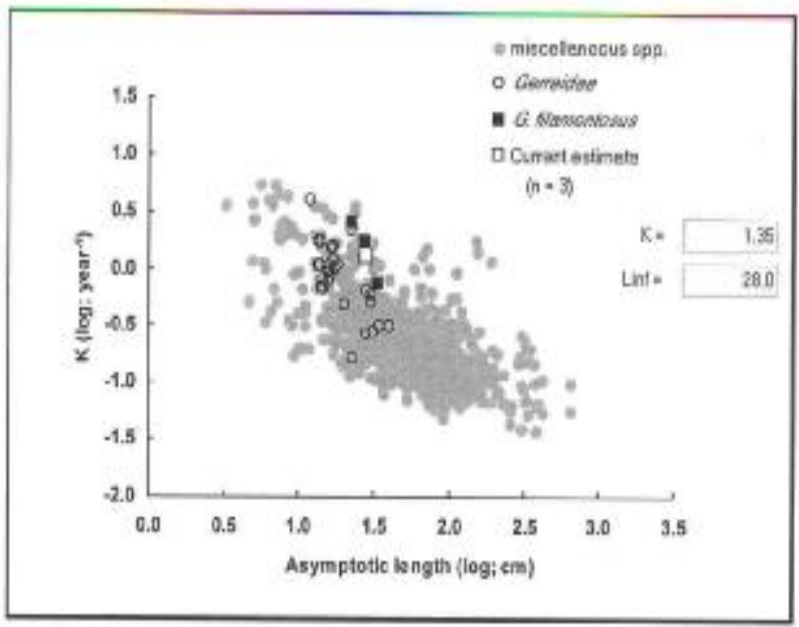

Fig. 7a. Auximetric plot for maleGerres abbreviatus

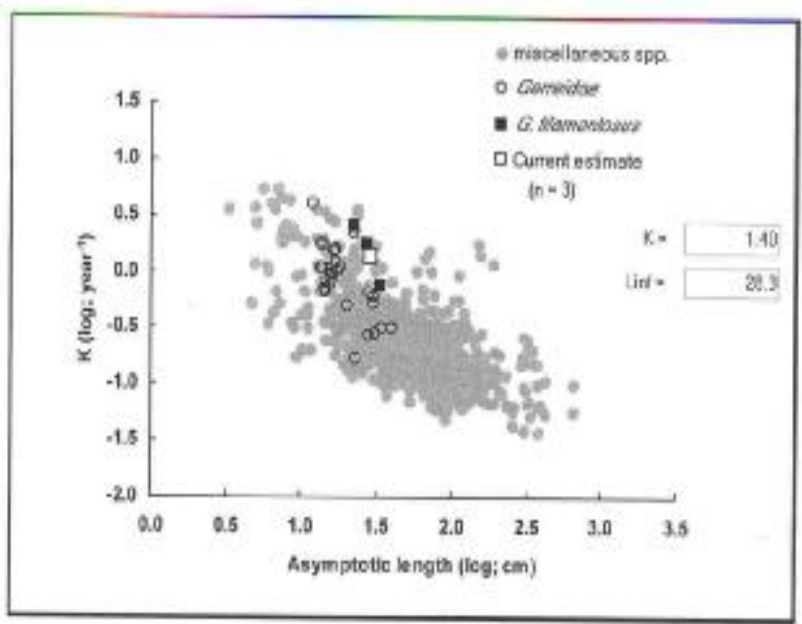

Fig. 7b. Auximetric plot for femaleGerres abbreviatus 


\section{Discussion}

The $\mathrm{L}_{\infty}, \mathrm{K}$ and $\mathrm{t}_{0}$ values of $G$. abbreviatus are not known. The maximum size of an organism is a strong predictor for many life history parameters (Blueweiss et al. 1978). The ' $\mathrm{b}$ ' for these species was also not known. The goodness of fit index $(\mathrm{R})$ for the obtained $\mathrm{K}$ and $\mathrm{L}_{\infty}$ values of male and female were 0.199 and 0.109 respectively. Usually, the R value ranges between 0 and 1 in the ELEFAN-FiSAT package. The oscillation parameter (C) and winter point were assumed to be 0 as it is a tropical species. The growth parameter estimates obtained as $\mathrm{I}_{\infty}$ and $\mathrm{K}$ for male and female Gerres abbreviatus were plotted on an 'auximetric' plot of $G$. filamentosus available in FishBase (Froese \& Pauly 2000) representing the $\log \mathrm{K}$ versus $\log \mathrm{L}_{\infty}$ values of 1300 species for which the above values are known. This was done to know the agreement of the estimated values (Figs. $7 \mathrm{a}$ and $7 \mathrm{~b}$ ) with the known values. From the figures it can be observed that the estimated values of the present study show consistency with the previously recorded values for this species and others. The estimated values of $\mathrm{K}, \mathrm{L}_{\infty}$ and $\mathrm{t}_{0}$ for congeners of G. abbreviatus are presented in Table 1 .

The estimated growth performance (Ø) index for male and female of this species is comparable with the $\varnothing$ value of 3.11 obtained for $G$. filamentosus from Madagascar waters (Pauly 1978). But the estimated values are slightly higher than the value of 2.56 obtained forG. oyena from Tanzania waters (Pauly 1978) and that of 2.55 for G. longirostris from Saudi Arabia waters (Pauly 1978). This clearly shows the reliability of the estimates of K and $\mathrm{L}_{\infty}$ in the present study. High annual growth rate of a fish can lead to high turnover rates or production per biomass (P:B) ratios (Gunderson 1997). Fast growth rate and small asymptotic length indicate that the fish species in these waters mature early in life and has a short life span (Sparre \& Venema 1992). The life span reported for G. filamentosus in Madagascar waters was 1.6 years (Pauly 1978). The results obtained in the present study for male and female G. abbreviatus (2.18 and 2.08) are quite higher than the earlier reported values for the congeners of the species (Sivashanthini \& Ajmal Khan 2004).

Among fish, natural mortality is found to be positively correlated with reproductive success (Gunderson 1997). Generally M/K is used as an index for checking the validity of $\mathrm{M}$ and $\mathrm{K}$ values estimated by different methods and it is known to range from 1 to 2.5 (Beverton \& Holt 1959). The $\mathrm{M} / \mathrm{K}$ ratios obtained in the present study for males and females (1.72 and 1.68) were well within this range. Instantaneous total mortality computed length converted catch curve forGerres setifer in the previous studies was 2.53 and 2.80 for males and females (Sivashathini \& Ajmal Khan 2004) and 
Table 1. The growth parameters estimated for gerreids from different regions of the world $(\mathrm{TL}=\mathrm{Total}$ length, $\mathrm{FL}=\mathrm{For} \overrightarrow{\mathrm{k}}$ length and $\mathrm{SL}=$ Standard length)

\begin{tabular}{|c|c|c|c|c|c|c|}
\hline Species & Sex & $\begin{array}{l}\mathbf{L}_{\infty} \\
(\mathbf{m m})\end{array}$ & $\begin{array}{l}K \\
\left(y^{-1}\right)\end{array}$ & $\begin{array}{l}\mathbf{t}_{0} \\
\left(\mathbf{y r}^{-1}\right)\end{array}$ & Region & Source \\
\hline $\begin{array}{l}\text { Pentaprion longimanus } \\
\text { P. longimanus } \\
\text { P. longimanus } \\
\text { P. longimanus } \\
\text { P. longimanus } \\
\text { P. longimanus } \\
\text { P. longimanus } \\
\text { P. longimanus } \\
\text { P. longimanus }\end{array}$ & $\begin{array}{l}\text { Unsexed } \\
\text { Unsexed } \\
\text { Unsexed } \\
\text { Unsexed } \\
\text { Male } \\
\text { Female } \\
\text { Unsexed } \\
\text { Unsexed } \\
\text { Unsexed } \\
\text { Unsexed } \\
\text { Unsexed } \\
\text { Unsexed } \\
\text { Unsexed } \\
\text { Unsexed } \\
\text { Unsexed }\end{array}$ & $\begin{array}{l}219 \mathrm{TL} \\
269 \mathrm{TL} \\
329 \mathrm{TL} \\
182 \\
174 \mathrm{TL} \\
170.5 \mathrm{TL} \\
\\
155 \\
137 \\
156 \\
134 \\
142 \\
160 \mathrm{TL} \\
158 \mathrm{FL} \\
172 \mathrm{FL} \\
170 \mathrm{FL}\end{array}$ & $\begin{array}{l}2.616 \\
1.788 \\
0.756 \\
1.1 \\
1.19 \\
1.26 \\
\\
0.94 \\
1.12 \\
0.80 \\
1.77 \\
1.8 \\
1.1 \\
1.00 \\
1.03 \\
1.59\end{array}$ & $\begin{array}{l}- \\
- \\
- \\
- \\
-0.0817 \\
-0.0775\end{array}$ & $\begin{array}{l}\text { Madagascar, Ambaro bay } \\
\text { Madagascar, Ambaro bay } \\
\text { Madagascar, Ambaro bay } \\
\text { Tanzania } \\
\text { South India } \\
\text { Australia } \\
\text { Indonesia } \\
\text { Indonesia } \\
\text { Indonesia } \\
\text { Indonesia } \\
\text { Malaysia } \\
\text { Philippines } \\
\text { Philippines } \\
\text { Philippines }\end{array}$ & $\begin{array}{l}\text { Pauly } 1978 \\
\text { Pauly } 1978 \\
\text { Pauly } 1978 \\
\text { Benno } 1992 \\
\text { Sivashanthini \& Ajmal } \\
\text { Khan } 2004 \\
\\
\text { Cabanban } 1991 \\
\text { Sadhotomo } 1983 \\
\text { Sadhotomo et al. } 1983 \\
\text { Sadhotomo et al. } 1983 \\
\text { Sadhotomo et al. } 1983 \\
\text { Chan \& Liew } 1986 \\
\text { Corpuz et al } 1985 \\
\text { Corpuz et al. } 1985 \\
\text { Ingles \& Pauly } 1984\end{array}$ \\
\hline
\end{tabular}


the values obtained in the present study are comparable with it. Only two earlier reports are available for gerreids on mortality estimates. Those are, for Pentaprion longimanus from the Philippines waters (Tandog-Edralin et al. 1988) where the natural mortality was found as 2.41 and for $G$. setifer from the Parangipettai waters (Sivashanthini \& Ajmal-Khan 2004) where the natural mortality was 1.26 and 1.32 for male and female.

In the relative yield per recruit and biomass per recruit prediction models the descending curves showed decrease in biomass / recruits ( $\left.\mathrm{B}^{\prime} / \mathrm{R}\right)$ as exploitation ratio increased for both male and female. The other curve showed increase in yield / recruit $\left(\mathrm{Y}^{\prime} / \mathrm{R}\right)$ with increase in exploitation ratio (E) up to $E_{\max }$. The $E_{\max }$ is the value of $E$ with the highest $Y^{\prime} / R$ value that is possible with a given value of $\mathrm{L}_{c}$ i.e. exploitation rate which produces maximum sustainable yield ( $\mathrm{E}_{\mathrm{MSY}}$ ) which represents the mean maximum catch that can be taken from the fishery without affecting the biology of the stock or the balance of the system. $E_{50}$ is the value of $E$ associated with a $50 \%$ reduction of the biomass (per recruit) in the unexploited stock. When harvesting at the MSY level, fishing mortality (F) is roughly equal to the natural mortality (M) and harvesting above MSY denotes over fishing. The present computed yield per recruit (selective ogive procedure) analysis showed exploitation rates (E) of 0.27 for males and 0.23 for females which are well below the predicted maximum value of 0.55 for both male and female. The implication is that the stock is not overexploited. Thus, the fishing pressure on the stock is not excessive. More yields could be obtained by a reasonable decrease in size at first capture without necessarily leading to over exploitation. However, reducing the stretched mesh size according to the minimum Lof 5.56 is not a good recommendation to increase the yield. As this may perhaps result in unsustainable fishery at one instance, the suggested recommendation is that increasing fishing efforts mainly by raising the number of boats to get optimum fishery in Parangipettai waters. Even though the data represent the boat seine fishery the conclusion would be realistic as boat seine is the extensive method contribute $80 \%$ of the capture fishery at Parangipettai waters.

\section{Acknowledgement}

The author is grateful to the University Grants Commission, New Delhi, India for financial assistance in the form of a Junior Research Fellowship. 


\section{References}

Amarasinghe, U. S. 2002.

The fishery and population dynamics of Oreochromis mossambicus and Oreochromis niloticus (Osteichthyes, Cichlidae) in a shallow Irrigation Reservoir in Sri Lanka. Asian Fisheries Science, 15(1): 7-20.

Amarasinghe, U. S. \& S. S. De Silva 1992.

Population dynamics of Oreochromis mossambicus and $O$. niloticus (Cichlidae) in two reservoirs of Sri Lanka. Asian Fisheries Science, 5: 37-61.

Anantha, C. S. \& P. Santha-Joseph 1995. Age and growth of Gerres setifer (Hamilton-Buchanan) inhabiting the coastal waters of Mangalore. Environmental Ecology 13(2): 406-409.

Beverton, R. J. H. \& S. J. Holt 1956.

A review of methods for estimating mortality rates in exploited fish populations, with special reference to sources of bias in catch sampling. Rapp. P. v. Réun. CIEM 140: 67-83.

Benno, B. L. 1992.

Some features of beach seine fishery aong the Dar es salaam coast, Tanzania. University of Kuopio, Department of Applied Zoology, Kuopio, MS thesis, $68 \mathrm{p}$.

Beverton, R. J. H. \& S. J. Holt 1959.

A review of the life spans and mortality rates of fish in nature and their relation to growth and other physiological characteristics, 142-180. In: Colloquia on aging (G. E. W. Wolstenholme \& M. O'Connor eds.), Vol. 5. The Lifespan of Animals, CIBA Foundation, London, Churchill.

Beverton, R. J. H. \& S. J. Holt 1966.

Manual of methods for fish stock assessment. Part 2. Tables of yield functions. FAO Fishery Technical Papers 38 Rev. 1: 67 p.

Blaber, S. J. M. 1978.

The fishes of the Kosi system. Lammergeyer 24: 28-41.

Blueweiss, L., H. Fox. V. Kudzman. D. Nakashima. R. Peters \& S. Sams 1978. Relationships between body size and some life history parameters. Oecologia 37: 257-272.

Cabanban, A. S. 1991.

The dynamics of Leiognathidae in tropical demersal ichthyofaunal community. James Cook University of North Queensland, Australia, Ph.D. dissertation, 262 p.

Chan, E. H. \& H. C. Liew 1986.

A study on tropical demersal species (Malaysia). Report to the International Development Research Centre: IDRC/3-A-83-1905, Singapore, $64 \mathrm{p}$. 
Chaudhuri, B. L. 1923.

Fauna of the Chilka Lake. Fish, Part IV. Memorandum of Indian Museum 5(11): 711-36.

Corpuz, A., J. Saeger \& V . Sambilay 1985.

Population parameters of commercially important fishes in Philippines waters. Technical Report of University of Philippines V isayas. Department of Marine Fisheries 6: 99 p.

Cyrus, D. P. 1980.

The biology of Gerreidae Bleeker, 1859 (Teleostei) in Natal

Estuaries. M.Sc. thesis, University of Natal, Pietermaritzburg.

Day, F. 1878.

The fishes of India, Bernard Quaritch, London.

Devasundaram, M. P. 1954.

A report on the fisheries of the Chilka Lake from 1948-1952.

Government Press, Cuttack: 1-34.

El-Agamy, A. E. 1988.

Age determination and growth studies of Gerres oyena (Forsk.) in the Arabian Gulf waters. Mahasagar 21(1): 2334.

Fournier, D. A., J. R. Sibert. J. Majkowski. \& J. Hampton. 1990.

MULTIFAN - a likelihood-based method for estimating growth parameters and age composition data sets illustrated by using data for southern bluefin tuna (Thunus maccoyii). Canadian Journnal of Fisheries and Aquatic Science 47(2): 301-317.

Froese, R. \& D. Pauly (eds.) 2000.

FishBase 2000: Concepts, design and data sources. ICLARM, Los Banos, Laguna, Philippines, 344 p.

Gayanilo, Jr., F. C \& D. Pauly (eds.) 1997.

The FAO-ICLARM Stock Assessment Tools (FiSAT) Reference manual. FAO Comparative information Series (Fish). No. (8). Rome, FAO, 262 p.

Gayanilo Jr., F. C., M. Soriano \& D. Pauly 1988.

A draft guide to the COMPLEA T ELEFAN. ICLARM Software Project 2: $65 \mathrm{p}$. and diskettes.

Gunderson, D. R. 1997.

Trade off between reproductive effort and adult survival in oviparous and viviparous fishes. Canadian Journal of Fisheries and Aquatic Science 54: 990-995.

Holden, S. \& M. Bravington 1991.

Length Frequency Data Analysis (LFDA). MRAG Ltd., London UK.

Ingles, J. \& D. Pauly 1984.

An atlas of the growth, mortality and recruitment of Philippines fishes. ICLARM Technical Report 13. International Center for Living Aquatic Resources Management, Manila, Philippines, 127 p. 
Iwatsuki, Y ., S. Kimura \& T. Y oshino 1999.

Redescription of Gerres erythorourus (Bloch, 1791), a senior synonym of $G$. abbreviatus Bleeker, 1850 (Teleostei: Perciformes: Gerreidae). Copeia 1: 165-172.

Jhingran, V. G. \& A. V. Natarajan 1966.

Final report on the fisheries of the Chilka Lake (1957-65). Bulletin of Central Inland Fisheries Research Institute, Burrackpore, (8).

Jhingran, V . G. \& A. V. Natarajan 1969.

A study of the fisheries and fish populations of the Chilka Lake during the period 195-65. Journal of Inland Fisheries Society of India 1: 49-126.

Jones, S. \& K. H. Sujasingani 1954.

Fish and fisheries of the Chilka Lake with statistics of fish catches for the years 1948-1950. Indian Journal of Fisheries 1 (1 and 2): 256-344.

Kaliyamurthy, M., S. K. Singh \& S. B. Singh 1986. Observations on the length-weight relationship and condition factor ofGerres lucidus Cuv. from the Pulicat Lake. International of Journal of Academy of Ichthyology, Modinagar 7(2): 21-25.

Kurup, B. M \& C. T. Samuel 1987. Length-weight relationship and relative condition factor in Daysciaena albida (Cuv.) and Gerres filamentosus (Cuv.). Fish Technological Society, Fishery Technology, Cochin 24(2): 88-92.

Kurup, B. M \& C. T. Samuel 1991. Spawning biology of Gerres filamentosus Cuvier in the Cochin estuary, Fishery Technology Society, Fishery Technology, Cochin 28(1): $19-24$.

Letourneur, Y. 1998.

Length-weight relationship of some marine fish species in Reunion Island, Indian Ocean. NAGA, ICLARM Quarterly 21(4): 37-39.

Moreau, J. 1987.

Mathematical and biological expression of growth in fishes: Recent trends and further developments, In: The age and growth of Fish (R. C. Summerfelt \& G. E. Hall (Eds.), The Iowa State University Press, pp. 18-113.

Mulyadi, E. 1988.

Estimation of biomass and biological parameters of Pentaprion longimanus (gerreidae) off the North Coast of Java, Indonesia, 246-256. In: Contributions to Tropical Fisheries Biology (S. C. V enema, J. M. Christensen \& D. Pauly eds.), FAO/DANIDA Follow-up training Course on Fish Stock Assessment in the Tropics, Denmark, 1986 and Philippines, 1987. FAO Fishery Report, $389 \mathrm{p}$.

Muto, E. Y., L. S. H. Soares \& C. L. D. B. Rossi-Wongtschowski 2000. Length-weight relationship of marine fish species off Sao 
Sebastiao System, Sao Paulo, Southeastern Brazil. NAGA, ICLARM Quarterly 23(3): 27-29.

Patnaik, S. 1971.

Observations on the fishery and biology of Chilka Jagili, Gerres setifer (Hamilton). Journal of Inland Fisheries Society of India 3: 25-43.

Pauly, D. 1978. A preliminary compilation of fish length growth parameters. Ber. Inst. Meereskd. Christian Albrechts University of Kiel 55: $1-200$.

Pauly, D. 1980.

A selection of simple methods for the assessment of tropical fish stocks. FAO Fishery Circular 729: 54pp. Issued also in French. Superseded by Pauly, D., 1983. FAO Fishery Technical Paper 234: $52 \mathrm{p}$.

Pauly, D. 1983.

Some simple methods for the assessment of tropical fish stocks.

FAO Fishery Technical Paper 234: 52 p.

Pauly, D. 1986a.

On improving operation and use of the ELEFAN programmes.

Pauly, D. 1986b.

Part II. Improving the estimation of $\mathrm{L}_{\mathrm{o}_{0}}$. Fishbyte 4: 18-20.

On improving operation and use of the ELEFAN programmes.

Part III. Correcting length-frequency data for effects of gear

Pauly, D. 1986c. selection and for incomplete recruitment. Fishbyte 4: 11-13.

On improving operation and use of the ELEFAN programmes. Part IV . Conclusions. Fishbyte 4: 14.

Pauly, D. 1987.

A review of the ELEFAN system for analysis of length-frequency data in fish and aquatic invertebrates. ICLARM Conference Proceedings 13: 7-34.

Pauly, D \& N. David 1981.

ELEFAN I, a BASIC program for the objective extraction of growth parameters from length-frequency data. Meeresforschung, 28(4): 205-211.

Pauly, D \& J. L. Munro 1984.

Once more on the comparison of growth in fish and invertebrates. Fishbyte 2-1: $21 \mathrm{p}$.

Powell, D. G. 1979.

Estimation of mortality and growth parameters from the length frequency of a catch. Rapp.P.-v.Réun.CIEM, 175: 167-169.

Prabhakara Rao, A. V. 1968.

Observations on the food and feeding habits of Gerres oyena (Forskal) and G. filamentosus Cuvier from the Pulicat Lake, with notes on the food of allied species. Journal of Marine Biological Association of India 10: 332-346. 
Prabhakara Rao, A. V. 1970.

Observations on some aspects of the biology of Gerres oyena (Forskal) with notes on the fishery of silver biddies of Pulicat Lake. Journal of Inland Fishery Society of India 2: 85-100.

Roy, J. C. \& N. Sahoo 1962.

Bulletin on the Development of Chilka Lake (Chilka Fisheries, 1949-1955). Orissa Government Press (5).

Sadhotomo, B. 1983.

The dynamics of travelly, Pentaprion longimanus at Java Sea.

Marine Fishery Research Report 28: 82 p.

Sivashanthini, K \& B. Abeyrami 2003. Length-weight relationship and condition factor of Gerres oblongus (Pisces: Perciformes) from the Jaffna lagoon, Sri Lanka. Indian Journal of Marine Sciences 32(3): 252254.

Sivashanthini, K. \& S. Ajmal-Khan 2004.

Population dynamics of Gerres setifer Hamilton, 1822 in the Parangipettai waters, Southeast coast of India. Indian Journal of Marine Sciences 33(4): 352-357.

Sparre, P. 1987.

Computer programs for fish stock assessment. Length-based fish stock assessment for Apple II computers. FAO Fishery Technical Paper 101(2): $218 \mathrm{p}$.

Sparre, P. \& S. C. Venama 1992.

Introduction to Tropical Fish Stock Assessment. Part I. Manual, FAO Fisheries Technical Paper No. 306/1: 376 p.

Tandog-Edralin, D., S. R. Ganaden. \& P. Fox 1988.

A comparative study of fish mortality rates in moderately and heavily fished areas of the Philippines, 468-481. In: Contributions to tropical fisheries biology (S. C. V enama, J. M. Christensen \& D. Pauly eds), FAO/DANIDA Follow-up Training Course on Fish Stock Assessment in the tropics, Denmark, 1986 and Philippines, 1987. FAO Fishery Report 389.

von Bertalanffy, L. 1938.

A quantitative theory of organic growth. (Inquiries on growth laws II), Human Biology 10: 181-213.

Wetherall, J. A. 1986.

A new method for estimating growth and mortality parameters from length-frequency data. ICLARM Fishbyte, 4(1): 12-14.

Yeeting, B. M. 1990.

Notes on the silverbiddy Gerres oyena (Gerreidae) in Tarawa Lagoon, Kiribati. Fishbyte 8(3): 8-10. 
